\title{
Legal protection on the rights of school honorary teachers
}

\author{
S. Awaliyah* \\ Universitas Negeri Malang, Malang, Indonesia
}

\begin{abstract}
The purpose of this article is to discuss legal protection for school honorary teachers in Malang. This study uses a socio-legal approach. Primary data sources are from school principals, teachers, and institution administrators. Moreover, secondary data sources come from laws and regulations relating to teachers' rights. Data are collected through documentation studies, interviews, and observations. Data analysis used domain and taxonomic analysis. Rights of teachers contained in Law Number 14 of 2005 include the right to get welfare and develop professionalism. This study concludes that the right of school honorary teachers in Malang to get welfare is still not good enough. It is due to the fact that they still get a salary below the city minimum wage. On the other hand, the right to develop professionalism or competence has been obtained well by the teachers.
\end{abstract}

Keywords: school honorary teachers, teacher salary, teacher welfare, teacher rights, teacher obligation

\section{INTRODUCTION}

The goal of the state is to educate the nation's life as set forth in Paragraph four of the Preamble of the 1945 Constitution of the Republic of Indonesia. Efforts to educate the nation are regulated through articles, including Article $28 \mathrm{C}$ paragraph (1), namely the right of every person to meet their basic needs, get education, and take advantage of science as a means of improving the quality of life and human welfare, not only for others but also for themselves. Citizens as part of the state have the right to obtain education as stipulated in 5 (five) paragraphs contained in Article 31 paragraph (1) of the 1945 Constitution. The state commitment to education implicitly can be seen in the very large allocation of state budget funds, amounting to $20 \%$ of the total state budget (Direktorat Penyusunan APBN dan Direktorat Jenderal Anggaran, 2019). The allocation of the funds is used to finance educational needs, especially for elementary education, construction of infrastructure, and salary of teachers.

Teachers are a crucial component in education. Teachers play roles as educators and means of social justice for students (Rust, 2019). Professionally, teachers are expected to have good qualities to help students to have good attitudes, knowledge and skills as a provision for life. The number of teachers in Malang City based on the database in 2020 is 9,679 people (Kemendikbud, 2020). The number of teachers of the state civil servants is 4,069 people $(42 \%)$ and non-state civil servants is 5,610 people (58\%). Non-state civil servants' teachers consist of permanent foundation teachers, provincial temporary teachers, central auxiliary teachers, and school honorary teachers. Permanent foundation teachers receive a salary according to the school's ability and are entitled to receive certification allowances for those who meet the requirements. Provincial temporary teachers and city/district temporary teachers receive salaries with the help of the provincial and city/district budget. Therefore, the salaries they receive are better.

The problem of this study is related to the status of honorary teachers in Malang, which is around 2,219 people. The salary of the teachers is paid based on the ability of the school, and do not get

\footnotetext{
${ }^{*}$ Corresponding Author
} 
assistance from the central or local government. Teachers have the same obligation, namely to provide good and high-quality educational services to students. Meanwhile, Law Number 14 of 2005 concerning Teachers and Lecturers regulates various rights of teachers to get a decent salary and quite a lot of other rights. This study is different from the previous study on foundation honorary teachers using the legal basis of Law Number 13 of 2003 concerning Manpower (Rifai, 2019). The discussion is based on Law Number 14 of 2005. This regulation does not exclude or do not divide the status of teachers as Civil Servants, temporary teachers, permanent teachers, auxiliary teachers, honorary teachers, or other teachers. Based on this, this paper will discuss the protection of the right to welfare and professional development of school honorary teachers.

\section{METHODS}

This study used socio legal methods. It aimed at revealing the behavior of schools or foundations in providing salaries to school honorary teachers in the schools (Tjandra, 2013). The study used a case study approach to capture data on the welfare of each school's honorary teachers (Soekanto, 1986). The research was conducted in Malang City, East Java Province, which is known as the city of education. Primary data were from school honorary teachers, school principals, and foundation administrators. While secondary data came from regulations concerning teachers, teacher learning plan documents, information about school honorary teachers on the internet, books, journals, and dictionaries. The data were collected through interviews, documentation study, and observation. The data analysis used was domain analysis and taxonomic analysis (Bungin, 2015).

\section{RESULTS AND DISCUSSION}

\subsection{The right to earn income for school honorary teacher's welfare}

The salary earned by honorary teachers is still very low, below the City/Regency Minimum Wage. The average fee earned is between IDR 20,000 and IDR 75,000 per hour, which is calculated based on the number of teaching hours in one month, not per meeting. Take, for example, if the fee is IDR 40,000 per hour, and a teacher is teaching 24 hours per week, then the salary earned in one month is IDR $40,000 \times 24$ hours $=$ IDR 960,000. This salary is far below the Minimum Work Wage based on the decree of Governor of East Java Number188/568/KPTS/013/2019 concerning Regency/City Minimum Wages in East Java. The minimum wage is remuneration for work for the performance of workers or employees (Wihastuti \& Rahmatullah, 2017). The salary of non-certified school honorary teachers is very far below the Minimum Wage of Malang City, which is IDR $2,600,000$.

Various salaries received by school honorary teachers are influenced by the tuition fees paid by students and the number of students. School fees include payments paid at the beginning of the school year and monthly fees. Favorite schools with high achievements tend to get more students and higher costs. Another example is Montessori school which relies on the use of learning media (Rohmatu, et al. 2020). The creation of the media needs a large fund. As a result, the school fee is also high-priced. It is more likely that the more expensive the school fee, then the higher salary the teachers get. On the other hand, undeveloped schools have a little interest and the school fees are low. Consequently, the salary of the school honorary teachers is also low. School conditions greatly affect the salary of school honorary teachers (Fauzi \& Syafar, 2017). This is in accordance with Article 15 paragraph (3) of Law Number 14 of 2005, which stipulates that teachers' salary in schools run by the community is adjusted to the capabilities of each school.

School honorary teachers also get a transportation allowance. It is between IDR 30,000 to IDR 100,000 per month. The calculation of the transportation allowance depends on the school institution where the teacher teaches and the number of teaching hours. There are two ways for calculating the transportation allowance, namely per meeting and per month. Social security received by school 
honorary teachers is health insurance. It is in the form of an insurance card that is valid for one year. The school supports the insurance by two ways, in accordance to the ability of the school. First, the school signs up for insurance and pays the insurance dues without cutting the salary of the teachers. Second, the school only registers for insurance and the teacher will pay the insurance dues.

School honorary teachers have the right to carry out other activities outside of teaching hours at schools in which they usually receive a certain amount of honorarium. Those other activities are temporary in nature which are carried out once a semester or once a year outside of teaching hours. Some of those activities include: (a) compiling exam questions, (b) being an examination supervisor, (c) test evaluation, (d) being a homeroom teacher, and (e) meetings at school or outside of school. In compiling questions, supervising exams, and correcting exams, the teacher will get an honorarium of IDR 15,000 to IDR 40,000. Each month, a homeroom teacher gets an honorarium of around IDR 30,000. The amount of honorarium for meetings or workshops in schools cannot be described on average because the activities vary widely.

This condition is far different from the income or salary of civil servant teachers. School honorary teachers only receive a monthly salary or honorarium based on the number of teaching hours; no functional allowances, professional allowances, and others. Meanwhile, the requirements to become teachers are all the same, which is having a bachelor degree according to the field of science and others. This difference is strongly influenced by several things, namely institutions, regulations that provide protection, and the culture of implementing the regulations (Friedman, 2019). Existing schools or institutions have not been able to provide school honorary teachers a salary or honorarium. School honorary teachers have not gotten adequate legal protection in relation to the salary which affects their welfare. Uncertainty about the status of school honorary teachers has resulted in education providers being able to pay very minimal wages for various reasons. This shows the legal culture of Indonesian society, namely social forces that can be decisive in implementing law (Erwin, 2013).

The income of school honorary teachers as a profession viewed from the Manpower Act is still far from standard. Income is closely related to welfare, which is a fulfillment of both material and non-material needs that are given outside or within a work relationship in order to increase productivity either directly or indirectly. Welfare is closely related to high income (Awaliyah, 2017). At the level of reality, the right to earn income above the necessities of life for school honorary teachers has not been fulfilled yet. It is due to the fact that school honorary teachers get a salary less than the minimum wage for cities and regions. This also contradicts Article 1 Number 16 of the Teacher and Lecturer Law, which states that the granting of teacher rights is due to their achievements and profession as educators.

The Considered to the Teacher and Lecturer Law states that the existence of the law is an effort to improve teacher quality in a directed, planned and sustainable manner. However, by not regulating school honorary teachers, particularly regarding the teachers' welfare, the quality of teachers is not optimal. The quality of teachers is not only influenced by internal factors such as abilities, skills, and experience, but is also influenced by external factors such as salaries (wages), leadership, work environment, and facilities and infrastructure (Arifin \& Barnawi, 2012). Salaries have a significant effect on teacher performance or quality (Sari, 2016; Hendrics, 2015). Meanwhile, the quality of teachers is one of the factors that influence the quality of education (Hidayat, 2016). The achievement of high-quality education cannot be separated from the fulfillment of adequate facilities and infrastructure, the availability of funds, quality human resources, and the welfare of educators (Nikmah, 2013). Thus, it is clear that the quality of education is greatly influenced by the welfare of teachers.

Furthermore, calculation of teacher workload is different from the workload of workers in general (Mustofa, 2018). The implementation of the workload for workers in general is 40 hours per week. One day is eight hours of work by using the five working day system, or seven hours by using the six working day system. For workers who have carried out the workload for 40 hours of work, they are entitled to receive the minimum wage set by the government. These working hours only apply to certain professions, not including teaching professions. For the teaching profession, the 
implementation of the workload is specifically regulated in Regulation of the Minister of Education and Culture Number 15 of 2018.

The teachers' workload at the base of administration for one week is 40 hours, namely 37.5 hours for effective work days and 2.5 hours for rest. It consists of planning, implementing, and assessing the learning being carried out. Besides, teachers have to provide guidance and various training to students. Certain teachers also get additional assignments, for example as a headmaster or vice headmasters of the school. They are also responsible for a minimum of 24 hours and a maximum of 40 hours for face-to-face meeting for one week. Working hours and face-to-face meeting hours are different. One hour of work is 60 minutes, while one hour of face-to-face meeting is different for each level of education; 35 minutes for elementary school, 40 minutes for junior high school, and 45 minutes for senior high school. Teachers who have implemented face-to-face learning for 40 hours do not mean that the teacher has carried out the obligation of 40 hours of work in one week because one hour of face-to-face meeting is not the same as 60 minutes. Therefore, even though the teacher has implemented 40 hours of face-to-face meeting, he must still be present at the base administrative unit to meet the total working hours, namely 40 hours.

Based on the calculations using a minimum teaching load of 24 hours face-to-face meeting, the income earned between civil servant teachers and school honorary teachers is far different. Based on Government Regulation Number 15 of 2019, a civil servant teacher at the lowest class of IIIA with a work period of 0 years gets a base salary of IDR 2,579,400, plus allowances and teacher certification one time of the basic salary. Minimum salary, allowances, and teacher certification are around IDR 6,000,000. While the obligations of civil servant and school honorary teachers that must be carried out are the same, namely (a) developing/making learning tools, (b) implementing learning, (c) evaluating student learning outcomes, and (d) carrying out various activities that support the provision of education in schools (Nurmal, 2018).

The obligation of teachers to prepare learning tools is one of absolute tasks (Novauli, 2015). School honorary teachers are also required to make learning tools that include annual programs, semester programs, syllabus, lesson plans, teaching materials, and evaluation. Teachers in carrying out learning must be creative and innovative in accordance with the character of students. The learning media used must be able to attract students. Therefore, the students have a higher enthusiasm for participating in learning and improving their achievement. Schools that have good performance will become favorite schools (Raharjo \& Yuliana, 2016) and get more attention from the community. Therefore, they will send their children to those schools. Schools usually charge the cost of creating media to teachers. Moreover, it often requires substantial funds. On the other hand, school honorary teachers' salaries are low or even very low. Then there will be no use of attractive media, because there is no money to create it.

\subsection{Protection and professionalism development of school honorary teachers}

Teachers' rights based on Law Number 14 of 2005 in Article 14, apart from getting a decent income, are to obtain various rights for development of personal, professionalism, competence, and protection for performance in carrying out their duties. In detail, these rights are the rights to get promotion and appreciation for their achievements, get protection in carrying out tasks, determine passing grade for students, get opportunities to improve competence, utilize infrastructure and facilities for carrying out tasks, get freedom to provide assessments, provide rewards and punishments to students, receive security and safety protection during on duty, provide advice or input related to educational policies, develop academic qualifications, participate in professional organizations, and attend training.

The granting of school honorary teachers' rights related to the development and protection of their professionalism as stated in the Teacher and Lecturer Law is effective. This can be seen in the implementation of the rights and obligations of the teacher. Teachers have the freedom to design learning according to their abilities and desires, carry out assessments, give students rewards and punishments as a coaching effort, participate in competitions, participate in various training/workshops/seminars, continue their studies, and become members of the profession. These 
various rights can be obtained by school honorary teachers according to the talents, interests and wishes of the teachers.

Protection on teachers as stipulated in Article 39 paragraph (4) of Law Number 14 Year 2005 aims at preventing teachers from getting arbitrary treatments. Take, for example, the provision of unreasonable wages or wages, termination of employment without a clear basis, harassment of the profession as a teacher, the expression of restricted views, and other restrictions that are feared becoming obstacles for teachers in carrying out their duties.

School honorary teachers get all protections sufficiently, except the protection of the salary. The teachers have the freedom to express their various opinions either verbally or in writing, of course they still have to pay attention to the applicable regulations. The school and the Education Office provide protections to school honorary teachers. Take, for example when there are problems between teachers and students or with other teachers, the school or the Education Office always provides assistance or acts as a mediator in solving various cases experienced by teachers.

The dismissal of school honorary teachers can be done with honor and disrespectfully. Teachers can be honorably discharged due to retirement, death, serious incurable illness, and at their own request. Dismissal of teachers with disrespect is because the teacher violates the promise and oath of office, violates the work agreement, and for one month or more successively neglects or does not heed his obligations. Schools cannot terminate work relations without an appropriate reason. Termination of employment for school honorary teachers in Malang City is mostly at the teachers' own request because they work elsewhere or are accepted as a candidate for civil servants.

\section{CONCLUSIONS}

Law Number 14 of 2005 concerning Teachers and Lecturers regulates teachers' rights related to professionalism and welfare for teachers. The granting of the rights to develop professionalism/ competence of school honorary teachers in Malang has been effective. The teachers can participate in various trainings, become members of teacher organizations, participate in various competitions, and others. Meanwhile, related to welfare, it is ineffective yet, because the amount of honorarium the teachers get is still below the city and regional minimum wages.

\section{REFERENCES}

Awaliyah, S. 2016. The effectiveness of anti-discrimination laws for job seekers in Indonesia. Journal of Law, Policy and Globalization 51(1): 41-48.

Bungin, B. 2015. Analisis data penelitian kualitatif. Jakarta: Raja Grafindo.

Direktorat Penyusunan APBN dan Direktorat Jenderal Anggaran. (2019). Informasi APBN 2019, APBN untuk mendorong investasi dan daya saing melalui pembangunan sumber daya manusia. Jakarta: Direktorat Jenderal Anggaran.

Erwin, M. 2013. Filsafat hukum. Jakarta: Rajawali Pers.

Fauzi, H. \& Syafar, D. 2017. Studi tentang kebijakan guru honor sekolah sekolah dasar di Yogyakarta. Jurnal manajemen Pendidikan Islam 5(2): 162-172.

Hendricks, M.D. 2015. Towards an optimal teacher salary schedule: Designing base salary to attract and retain effective teachers. Economics of Education Reviews 47(C): 143-167.

Hidayat, E. 2014. Faktor-faktor yang mempengaruhi mutu sekolah (Pengaruh dari faktor kinerja mengajar guru dan pemanfaatan sumber belajar). Jurnal Administrasi Pendidikan 21(1): 81-88.

Friedman, L.M. 2009. Sistem hukum (perspektif ilmu sosial). (Khozin, M. Trans). Bandung: Nusa Media.

Kemendikbud. 2020. Guru menurut status kepegawaiannya. Retrieved from https://referensi.data.kemdikbud. go.id/dashboardgtk/ptk_dash2.php?id=20

Mustofa, M. 2018. Menghitung beban kerja guru. Jurnal Audi Kajian Teori dan Praktik di Bidang Pendidikan Anak Usia Dini 3(1): 64-69.

Nikmah. 2013. Pengorganisasian layanan pendidikan boarding school berorientasi mutu. Educational Management 2(1): 107-112. 
Novauli, M.F. 2015. Kompetensi guru dalam peningkatan prestasi belajar pada SMP Negeri Dalam Kota Banda Aceh. Jurnal Administrasi Pendidikan 3(1): 45-67.

Nurmal, L.D. 2018. Perlindungan hukum terhadap tenaga pendidik. Gorontalo Law Review 1(1): 67-76

Raharjo, S.B. \& Yuliana, L. 2016. Manajemen sekolah untuk mencapai sekolah unggul yang menyenangkan: Studi kasus di SMAN 1 Sleman Yogyakarta. Jurnal Pendidikan dan Kebudayaan 1(2): 203-217.

Republik Indonesia. 2005. Undang-Undang Nomor 14 Tahun 2005 tentang Guru dan Dosen.

Rifai, A. 2019. Perlindungan hukum terhadap hak-hak bekerja guru yayasan dengan guru honor sekolah sekolah negeri ditinjau dari Undang-Undang Nomor 13 Tahun 2003 Tentang Ketenagakerjaan. Jurnal Unizar Law Review 2(2): 158-168.

Rohmatu, H.P. et al. 2020. Kajian komparatif sistem among dan metode montessori. Jurnal Ilmiah Pendidikan Pancasila dan Kewarganegaraan 5(2): 261-270.

Rust, F.O. 2019. Redesign in teacher education: The roles of teacher educators. European Journal of Teacher Education 42(4): 523-533.

Sari, W.P. 2016. Pengaruh gaji dan motivasi terhadap kinerja guru pada SMA Swasta Bagan Sinembah, Rokan Hilir, Riau. Tingkap 12(1): 65-81.

Soekanto, S. 1986. Pengantar penelitian hukum. Jakarta: UI Press.

Tjandra, S. 2013. Sosio legal bekal pengantar dan substansi pendalaman. Malang: Intimedia.

Wihastuti, L. \& Rahmatullah, H. 2017. Upah minimum provinsi (UMP) dan penyerapan tenaga kerja di Pulau Jawa. Jurnal Gama Societa 1(1): 96-102. 